\title{
Risk of Anaemia in Population of Healthy Young People Inhabiting a Region in Central Europe
}

\author{
Małgorzata Szczuko, ${ }^{1}$ Izabela Gutowska, ${ }^{1}$ Teresa Seidler, ${ }^{2}$ Mariusz Mierzwa, \\ Ewa Stachowska, ${ }^{1}$ and Dariusz Chlubek ${ }^{3}$ \\ ${ }^{1}$ Department of Biochemistry and Human Nutrition, Pomeranian Medical University, Szczecin, Poland \\ ${ }^{2}$ Department of Human Nutrition, West Pomeranian University of Technology, Szczecin, Poland \\ ${ }^{3}$ Department of Biochemistry and Medical Chemistry, Pomeranian Medical University, Szczecin, Poland
}

Correspondence should be addressed to Małgorzata Szczuko; szczukom@poczta.onet.pl

Received 24 April 2013; Revised 20 June 2013; Accepted 26 June 2013

Academic Editor: Duo Li

Copyright (C) 2013 Małgorzata Szczuko et al. This is an open access article distributed under the Creative Commons Attribution License, which permits unrestricted use, distribution, and reproduction in any medium, provided the original work is properly cited.

It is quite unbelievable but significant percentage of young healthy women is at risk of anaemia despite proper nutritional state. In this study we decided to determine the lack or excess of which nutrients in a diet can lead to any effects. The major cause of anaemia is not, as in many studies on nutritional status, the deficiency in iron in a diet. Iron intake in women with anaemia exceeded AI (Adequate Intake) level. 120 people took part in the study. Average HGB concentration in female group amounted to $12.45 \mathrm{~g} / \mathrm{dL}$ and in male group to $14.35 \mathrm{~g} / \mathrm{dL}$. Anaemia was determined in $29 \%$ women and $4.2 \%$ men. In group of women with anaemia a statistically higher intake of SFA, cholesterol, and sucrose and lower intake of pyridoxine, folacin, niacin, and vitamin $\mathrm{E}, \mathrm{Mn}, \mathrm{Cu}$, $\mathrm{Zn}, \mathrm{Fe}$, and $\mathrm{Mg}$ were determined. In a group of men with low haemoglobin concentration a statistically higher intake of sucrose but lower intake of fat, especially SFA and MUFA, vitamin C and zinc were observed. Therefore, together with anaemia in the group of women there are coexisting deficiencies in other nutrients, as compared to the group of men. Prevention in both groups should include various supplements.

\section{Introduction}

Present-day diseases of affluence are often the effect of improper nutrition. It is considered that the fundamental cause of diet-related diseases is improperly balanced diet and wrong eating habits. Many experts think that young people cope well with excessive or deficient intake of nutrients. The aim of our study was to determine whether nutritional mistakes made in group of young educated people can be the cause of disorders and lead to diseases in their future life and the life of their children. It is especially important because whole Europe, as well as USA, deal more often with the issue of excessive intake of nutrients and increased percentage of obese people among the youth than with diseases connected to malnutrition $[1,2]$. With respect to this, particularly dangerous is the deficiency in folacin in women's diets, particularly for women planning pregnancy, because it can lead to underdeveloped placenta and, in consequence, to miscarriage or neural tube defects in neonates [3]. In
Poland, neural tube defects occur in 2-3 cases per 1000 births [4]. Another result of folacin deficiency is susceptibility of cells to neoplastic transformation, especially with respect to large intestine [5], increased risk of psychical disorders of depressive character [6], and occurrence of megaloblastic anaemia, characterized with lowered number of red cells simultaneously increased in size. We determined which nutrients are most responsible for changes in haemoglobin concentration in blood, considering sex and current eating trends among young people. The study involved the students of Food Technology and Human Nutrition, whose knowledge on proper diet is higher than in populations of students of other specializations.

\section{Material and Methods}

2.1. Examined Group. The examination was carried out on students of Food Technology and Human Nutrition, 
volunteers, at the age of 22-24. Examined group comprised of 120 people, 96 women and 24 men. The study was approved by Bioethics Commission at the Pomeranian Medical University in Szczecin (N-001/12/06).

\subsection{Interpretation of Haemoglobin and Hematocrit Tests} Results. Reference ranges for HGB concentration (according to WHO definition) were considered as $12-16 \mathrm{mg} / \mathrm{dL}$ for women and $13-18 \mathrm{mg} / \mathrm{dL}$ for men. In examined group there were no people with anaemia.

Taking into consideration the results of complete blood count, the students were divided into three groups on the basis of haemoglobin concentration in blood, taking into account their sex. Different ranges of haemoglobin concentration were determined in female and male groups.

In the female group the ranges were as follows:

(i) I group with haemoglobin concentration $<12 \mathrm{~g} / \mathrm{dL}$;

(ii) II group with haemoglobin concentration $12-13 \mathrm{~g} / \mathrm{dL}$;

(iii) III group with haemoglobin concentration $>13 \mathrm{~g} / \mathrm{dL}$.

Among the men the following groups were distinguished:

(i) I group with haemoglobin concentration $<14 \mathrm{~g} / \mathrm{dL}$;

(ii) II group with haemoglobin concentration $14-15 \mathrm{~g} / \mathrm{dL}$;

(iii) III group with haemoglobin concentration $>15 \mathrm{~g} / \mathrm{dL}$.

In each of the previous groups of examined people, a nutritional assessment was made on the basis of nutrients content in 7-day food diary.

2.3. Blood Biochemical Tests. Blood was collected after fasting into a tube containing ethylenediaminetetraacetic acid (EDTA) as anticoagulant in form of film sprayed onto the walls of a tube for quantitative and qualitative analyses of blood morphotic elements.

2.4. Computer and Statistical Analysis of Nutrition. In students' diets the assessment included the contents of energy, selected nutrients (protein, total fat, SFA, MUFA, and PUFA, and carbohydrates, including sucrose, vitamins $A, D, E, C$, $\mathrm{B}_{1}, \mathrm{~B}_{2}, \mathrm{~B}_{6}$, and $\mathrm{B}_{12}$, niacin, folacin, and mineral compounds: sodium, potassium, calcium, phosphorus, magnesium, iron, zinc, copper, manganese, and fibre, and cholesterol), and was performed using computer software "Dietician 2" and "Food composition tables" [7]. The calculation included correction indexes relating to losses occurring during storage and culinary treatment of food products.

To calculate significance of differences between the average values Tuckey's range test was used at the 0.05 level of significance (Statistica v 8.0).

\section{Results}

3.1. Interview and General Examinations. Examined students formed a random group where average BMI (body mass index) for women was 21.2 and for men 23.4. Taking into consideration a normal BMI in young people ranging from
TABLE 1: Average values of selected blood morphology parameters.

\begin{tabular}{lcccc}
\hline \multirow{2}{*}{ Parameters } & \multicolumn{2}{c}{ Women } & \multicolumn{2}{c}{ Men } \\
& $\bar{x}$ & SD & $\bar{x}$ & SD \\
\hline HGB (g/dL) & $12.45^{*}$ & 0.86 & $14.34^{*}$ & 1.37 \\
RBC (M/uL) & 4.30 & 0.33 & 4.87 & 0.49 \\
HCT (\%) & $37.9^{*}$ & 2.45 & $43.59^{*}$ & 3.87 \\
MCH (pg) & 29.21 & 2.23 & 29.71 & 1.00 \\
\hline
\end{tabular}

* Statistically significant difference with $P<0.05$; \%: percentage of people with proper levels of lipid profile parameters; $\bar{x}$ : average content in a group.

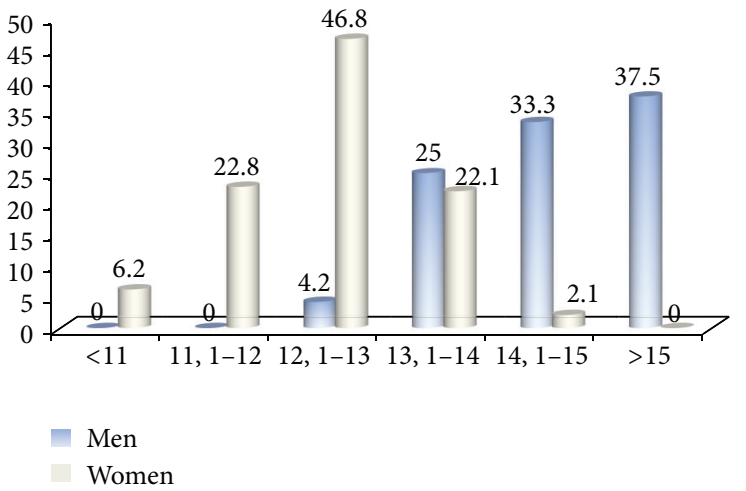

FIGURE 1: Percentage (\%) of people examined in analysed ranges of haemoglobin concentration $(\mathrm{g} / \mathrm{dL})$.

18.5 to $24.9 \mathrm{~kg} / \mathrm{m}^{2}$ [8], in female group $81.2 \%$ women had proper body weight, and the same percentage (9.4\%) had BMI $<18.5$ and $\mathrm{BMI}>24.9$. In male group $66 \%$ population had proper body weight, $8 \%$ were men with $\mathrm{BMI}<18.5$ and 25 with BMI $>24.9$. Average values of WHR (waist-hip ratio), which in women should reach $\leq 0.8$ and in men $\leq 0.95$, were 0.79 and 0.93 , respectively.

3.2. Daily Food Rations (DFR) Composition with respect to Blood Morphology in Plasma (CBC). Average values of selected blood morphology parameters in female and male groups were within reference ranges (Table 1). Average haemoglobin concentration (HGB), red blood count (RBC), packed cell volume (HCT), and mean cell haemoglobin (MCH) in women amounted to $12.45 \mathrm{~g} / \mathrm{dL}, 4.3 \mathrm{M} / \mathrm{ul}, 37.9 \%$, and 29.21 pico gram, respectively, whilst in men to $14.34 \mathrm{~g} / \mathrm{dL}$, $4.87 \mathrm{M} / \mathrm{ul}, 43.59 \%$ and 29.71 pico gram, respectively (Table 1 ). Statistical analysis of obtained results revealed that HGB and HCT in blood of men were significantly higher. It was determined that $29 \%$ women and only $4.2 \%$ men, according to WHO definition, had average HBG showing on anaemia (Figure 1). The highest percentage of women (46.8) had normal HGB concentration within the range from $12.1 \mathrm{~g} / \mathrm{dL}$ to $13 \mathrm{~g} / \mathrm{dL}$, whereas in male group the distribution of HGB concentration levels within the three ranges (from 13.1 to $15.0 \mathrm{~g} / \mathrm{dL}$ ) was more even (Figure 1).

3.3. Composition of Daily Food Rations (DFR) with respect to Haemoglobin Concentration in Blood. In the first group of women with the lowest haemoglobin concentration 
TABLE 2: Women's DFR composition with respect to haemoglobin concentration in blood.

\begin{tabular}{|c|c|c|c|c|c|c|}
\hline \multirow{3}{*}{ Parameter } & \multicolumn{6}{|c|}{ Haemoglobin concentration ranges $(\mathrm{g} / \mathrm{dL})$} \\
\hline & \multicolumn{2}{|c|}{$\mathrm{HGB}<12 \mathrm{~g} / \mathrm{dL}$} & \multicolumn{2}{|c|}{$12.1-13.0 \mathrm{~g} / \mathrm{dL}$} & \multicolumn{2}{|c|}{$\mathrm{HGB}>13.0 \mathrm{~g} / \mathrm{dL}$} \\
\hline & $\bar{x}$ & SD & $\bar{x}$ & $\mathrm{SD}$ & $\bar{x}$ & SD \\
\hline Energy (kcal) & $1763^{\mathrm{a}}$ & 708.5 & $1729^{a}$ & 292.7 & $1730^{\mathrm{a}}$ & 325.4 \\
\hline Protein $(g)$ & $60.87^{\mathrm{a}}$ & 22.55 & $61.94^{\mathrm{a}}$ & 12.85 & $61.92^{\mathrm{a}}$ & 10.46 \\
\hline Fat $(g)$ & $68.45^{\mathrm{a}}$ & 27.52 & $69.02^{\mathrm{a}}$ & 15.84 & $65.06^{\mathrm{a}}$ & 16.59 \\
\hline SFA (g) & $25.56^{\mathrm{b}}$ & 11.37 & $25.20^{\mathrm{ab}}$ & 6.37 & $23.11^{\mathrm{a}}$ & 8.01 \\
\hline MUFA (g) & $27.42^{\mathrm{a}}$ & 11.01 & $28.09^{\mathrm{a}}$ & 6.86 & $25.58^{\mathrm{a}}$ & 7.10 \\
\hline PUFA (g) & $10.33^{\mathrm{a}}$ & 3.45 & $10.42^{\mathrm{a}}$ & 3.18 & $11.24^{\mathrm{a}}$ & 5.06 \\
\hline Cholesterol (mg) & $241.6^{\mathrm{b}}$ & 102.07 & $242.3^{\mathrm{b}}$ & 73.05 & $207.8^{\mathrm{a}}$ & 71.91 \\
\hline Carbohydrates (g) & $235.3^{\mathrm{a}}$ & 95.31 & $226.6^{\mathrm{a}}$ & 42.25 & $228.3^{\mathrm{a}}$ & 50.03 \\
\hline Sucrose $(g)$ & $68.01^{b}$ & 34.30 & $55.43^{\mathrm{a}}$ & 21.22 & $54.84^{\mathrm{a}}$ & 17.08 \\
\hline Lactose (g) & $8.54^{\mathrm{a}}$ & 4.70 & $7.93^{\mathrm{a}}$ & 3.98 & $8.65^{\mathrm{a}}$ & 3.83 \\
\hline Dietary fibre (g) & $15.37^{\mathrm{a}}$ & 5.34 & $15.74^{\mathrm{a}}$ & 3.80 & $15.97^{\mathrm{a}}$ & 3.69 \\
\hline $\mathrm{Na}(\mathrm{mg})$ & $1684^{\mathrm{a}}$ & 567.17 & $1804^{\mathrm{a}}$ & 600.59 & $1824^{\mathrm{a}}$ & 323.58 \\
\hline $\mathrm{K}(\mathrm{mg})$ & $2368^{\mathrm{a}}$ & 990.06 & $2372^{\mathrm{a}}$ & 454.76 & $2462^{\mathrm{a}}$ & 727.50 \\
\hline $\mathrm{Ca}(\mathrm{mg})$ & $596.2^{\mathrm{a}}$ & 247.38 & $549.2^{\mathrm{a}}$ & 178.75 & $568.5^{\mathrm{a}}$ & 214.10 \\
\hline $\mathrm{P}(\mathrm{mg})$ & $1003^{\mathrm{a}}$ & 367.57 & $1019^{\mathrm{a}}$ & 214.27 & $1039^{a}$ & 174.92 \\
\hline $\mathrm{Mg}(\mathrm{mg})$ & $231.6^{\mathrm{a}}$ & 97.54 & $232.1^{\mathrm{a}}$ & 43.96 & $255.6^{\mathrm{b}}$ & 60.35 \\
\hline $\mathrm{Fe}(\mathrm{mg})$ & $8.91^{\mathrm{a}}$ & 3.27 & $8.91^{\mathrm{a}}$ & 1.65 & $10.07^{\mathrm{b}}$ & 4.50 \\
\hline $\mathrm{Zn}(\mathrm{mg})$ & $7.92^{\mathrm{a}}$ & 2.70 & $8.13^{\mathrm{ab}}$ & 1.66 & $8.78^{\mathrm{b}}$ & 4.39 \\
\hline $\mathrm{Cu}(\mathrm{mg})$ & $0.96^{\mathrm{a}}$ & 0.35 & $0.94^{\mathrm{a}}$ & 0.18 & $1.19^{\mathrm{b}}$ & 0.58 \\
\hline $\mathrm{Mn}(\mathrm{mg})$ & $3.70^{\mathrm{a}}$ & 1.25 & $3.81^{\mathrm{ab}}$ & 1.01 & $4.15^{\mathrm{b}}$ & 1.77 \\
\hline Vitamin A $(\mu \mathrm{g})$ & $990.3^{\mathrm{a}}$ & 1586 & $863.9^{\mathrm{a}}$ & 935.44 & $1012^{\mathrm{a}}$ & 1465 \\
\hline Vitamin D $(\mu \mathrm{g})$ & $2.83^{\mathrm{a}}$ & 1.66 & $2.73^{\mathrm{a}}$ & 1.96 & $2.55^{\mathrm{a}}$ & 1.80 \\
\hline Vitamin E (mg) & $7.36^{\mathrm{a}}$ & 2.50 & $7.52^{\mathrm{a}}$ & 2.19 & $8.37^{\mathrm{b}}$ & 4.04 \\
\hline Vitamin B1 (mg) & $0.84^{\mathrm{a}}$ & 0.33 & $0.93^{\mathrm{a}}$ & 0.31 & $0.87^{\mathrm{a}}$ & 0.13 \\
\hline Vitamin B2 (mg) & $1.24^{\mathrm{a}}$ & 0.43 & $1.29^{\mathrm{a}}$ & 0.43 & $1.32^{\mathrm{a}}$ & 0.16 \\
\hline Niacin (mg) & $11.98^{\mathrm{a}}$ & 5.56 & $13.26^{\mathrm{a}}$ & 4.40 & $16.88^{\mathrm{b}}$ & 12.01 \\
\hline Vitamin B6 (mg) & $1.35^{\mathrm{a}}$ & 0.57 & $1.53^{\mathrm{b}}$ & 0.49 & $1.55^{\mathrm{b}}$ & 0.85 \\
\hline Folacin $(\mu \mathrm{g})$ & $145.5^{\mathrm{a}}$ & 68.82 & $145.1^{\mathrm{a}}$ & 41.89 & $185.6^{\mathrm{b}}$ & 122.9 \\
\hline Vitamin B12 $(\mu \mathrm{g})$ & $3.41^{\mathrm{a}}$ & 3.70 & $3.45^{\mathrm{a}}$ & 2.84 & $4.32^{\mathrm{a}}$ & 7.95 \\
\hline Vitamin C (mg) & $52.66^{\mathrm{ab}}$ & 104.18 & $39.02^{\mathrm{a}}$ & 19.43 & $65.66^{\mathrm{b}}$ & 103.7 \\
\hline$\%$ Energy from protein & $13.6^{\mathrm{a}}$ & 2.96 & $14.1^{\mathrm{a}}$ & 3.05 & $14.1^{\mathrm{a}}$ & 3.08 \\
\hline$\%$ Energy from fat & $35.5^{\mathrm{a}}$ & 6.39 & $36.5^{\mathrm{a}}$ & 6.35 & $34.4^{\mathrm{a}}$ & 6.11 \\
\hline \% Energy from carbohydrates & $50.9^{\mathrm{a}}$ & 6.24 & $49.4^{\mathrm{a}}$ & 8.37 & $51.5^{\mathrm{a}}$ & 6.33 \\
\hline
\end{tabular}

${ }^{\mathrm{a}, \mathrm{b}}$ Homogenous groups according to Tuckey's test.

(HGB $<12 \mathrm{~g} / \mathrm{dL}$ ) a significantly higher intake of SFA (on average by $2.45 \mathrm{~g} /$ day), cholesterol (on average by $33.8 \mathrm{mg} /$ day), and sucrose (on average by $13.2 \mathrm{~g} /$ day) was observed, as compared to the intake in the third group characterized by the highest level of haemoglobin (HGB > $13 \mathrm{~g} / \mathrm{dL}$ ) (Table 2). Moreover women with the highest level of haemoglobin in blood consumed significantly higher amounts of magnesium (on average by 23.5 and $24 \mathrm{mg} /$ day), iron (on average by $1.16 \mathrm{mg} /$ day in both groups), copper (on average by 0.25 and $0.23 \mathrm{mg}$ ), vitamin $\mathrm{E}$ (on average by 1 and $0.85 \mu \mathrm{g} /$ day), niacin (on average by 4.9 and $3.62 \mathrm{mg} /$ day), and folacin (on average by 40.1 and $40.5 \mu \mathrm{g} /$ day) than women from other two groups and more zinc (on average by $0.86 \mathrm{mg} /$ day), manganese (on average by $0.45 \mathrm{mg} / \mathrm{day}$ ), and pyridoxine (on average by $0.2 \mathrm{mg} /$ day) than women from the first group, and vitamin $\mathrm{C}$ (on average by $26.64 \mathrm{mg} /$ day) than women from the second group. The remaining analysed nutrients (energy, protein, MUFA, PUFA, carbohydrates, lactose, dietary fibre, sodium, potassium, calcium, phosphorus, vitamins A and $\mathrm{D}$, thiamine, riboflavin, and cobalamin) were consumed on similar levels in all respective groups of women (Table 2). In male population there were no such significant differences in DFR composition as in female population (Table 3). First group with the lowest haemoglobin level (HGB $<14 \mathrm{~g} / \mathrm{dL}$ ) was the most uniform group with respect to consumption of all of the analysed nutrients, as compared to other groups, and the analysed consumption was the lowest in this group. In the group with intermediate HGB concentration (14.1$15.0 \mathrm{~g} / \mathrm{dL}$ ) a significantly higher intake of fat (on average by $17.9 \mathrm{~g} /$ day), SFA (on average by $7.1 \mathrm{~g} /$ day) and MUFA 
TABLE 3: Men's DFR composition with respect to haemoglobin concentration in blood.

\begin{tabular}{|c|c|c|c|c|c|c|}
\hline \multirow{3}{*}{ Parameter } & \multicolumn{6}{|c|}{ Haemoglobin concentration ranges $(\mathrm{g} / \mathrm{dL}) n=24$} \\
\hline & \multicolumn{2}{|c|}{$\mathrm{HGB}<14 \mathrm{~g} / \mathrm{dL}$} & \multicolumn{2}{|c|}{$14.1-15.0 \mathrm{~g} / \mathrm{dL}$} & \multicolumn{2}{|c|}{$\mathrm{HGB}>15.0 \mathrm{~g} / \mathrm{dL}$} \\
\hline & $\bar{x}$ & SD & $\bar{x}$ & SD & $\bar{x}$ & SD \\
\hline Energy (kcal) & $2159^{\mathrm{a}}$ & 724.6 & $2364^{\mathrm{a}}$ & 496.06 & $2308^{\mathrm{a}}$ & 707.2 \\
\hline Protein $(\mathrm{g})$ & $80.32^{\mathrm{a}}$ & 27.53 & $79.88^{\mathrm{a}}$ & 15.24 & $80.09^{\mathrm{a}}$ & 15.73 \\
\hline Fat $(g)$ & $83.06^{\mathrm{a}}$ & 34.30 & $101.0^{\mathrm{b}}$ & 19.32 & $96.76^{\mathrm{ab}}$ & 36.23 \\
\hline SFA (g) & $29.68^{\mathrm{a}}$ & 15.22 & $36.77^{\mathrm{b}}$ & 8.87 & $36.13^{\mathrm{ab}}$ & 16.23 \\
\hline MUFA (g) & $33.01^{\mathrm{a}}$ & 11.85 & $40.73^{\mathrm{b}}$ & 7.20 & $39.54^{\mathrm{ab}}$ & 15.14 \\
\hline PUFA (g) & $14.10^{\mathrm{a}}$ & 4.92 & $15.67^{\mathrm{a}}$ & 5.05 & $13.65^{\mathrm{a}}$ & 2.79 \\
\hline Cholesterol (mg) & $280.8^{\mathrm{a}}$ & 109.5 & $290.9^{\mathrm{ab}}$ & 112.59 & $359.4^{\mathrm{b}}$ & 185.8 \\
\hline Carbohydrates (g) & $289.1^{\mathrm{a}}$ & 90.20 & $305.2^{\mathrm{a}}$ & 77.75 & $287.4^{\mathrm{a}}$ & 63.64 \\
\hline Sucrose $(\mathrm{g})$ & $61.23^{\mathrm{ab}}$ & 23.29 & $75.23^{\mathrm{b}}$ & 21.37 & $57.72^{\mathrm{a}}$ & 14.16 \\
\hline Lactose (g) & $12.79^{\mathrm{a}}$ & 8.54 & $10.02^{\mathrm{a}}$ & 7.35 & $11.68^{\mathrm{a}}$ & 7.47 \\
\hline Dietary fibre (g) & $18.91^{\mathrm{a}}$ & 9.87 & $22.13^{\mathrm{a}}$ & 9.53 & $18.26^{\mathrm{a}}$ & 4.16 \\
\hline $\mathrm{Na}(\mathrm{mg})$ & $2122^{\mathrm{a}}$ & 911.7 & $2448^{\mathrm{b}}$ & 577.4 & $2568^{\mathrm{b}}$ & 849.6 \\
\hline $\mathrm{K}(\mathrm{mg})$ & $3022^{\mathrm{a}}$ & 1270 & $3156^{\mathrm{a}}$ & 1077 & $2724^{\mathrm{a}}$ & 621.3 \\
\hline $\mathrm{Ca}(\mathrm{mg})$ & $797.1^{\mathrm{a}}$ & 565.3 & $698.6^{\mathrm{a}}$ & 150.8 & $722.1^{\mathrm{a}}$ & 319.8 \\
\hline $\mathrm{P}(\mathrm{mg})$ & $1330^{\mathrm{a}}$ & 603.5 & $1361^{\mathrm{a}}$ & 310.7 & $1323^{\mathrm{a}}$ & 257.9 \\
\hline $\mathrm{Mg}(\mathrm{mg})$ & $291.8^{\mathrm{a}}$ & 147.27 & $320.2^{\mathrm{a}}$ & 119.5 & $276.9^{\mathrm{a}}$ & 49.10 \\
\hline $\mathrm{Fe}(\mathrm{mg})$ & $11.14^{\mathrm{a}}$ & 4.11 & $12.73^{\mathrm{a}}$ & 2.53 & $11.35^{\mathrm{a}}$ & 2.54 \\
\hline $\mathrm{Zn}(\mathrm{mg})$ & $10.05^{\mathrm{a}}$ & 2.82 & $11.75^{\mathrm{b}}$ & 2.83 & $10.76^{\mathrm{ab}}$ & 2.17 \\
\hline $\mathrm{Cu}(\mathrm{mg})$ & $1.19^{\mathrm{a}}$ & 0.64 & $1.23^{\mathrm{a}}$ & 0.52 & $1.07^{\mathrm{a}}$ & 0.18 \\
\hline $\mathrm{Mn}(\mathrm{mg})$ & $4.53^{\mathrm{a}}$ & 1.78 & $5.91^{\mathrm{b}}$ & 2.30 & $4.32^{\mathrm{a}}$ & 1.60 \\
\hline Vitamin A $(\mu \mathrm{g})$ & $832.4^{\mathrm{a}}$ & 971.54 & $1015^{\mathrm{a}}$ & 605.26 & $967.4^{\mathrm{a}}$ & 990.6 \\
\hline Vitamin D $(\mu \mathrm{g})$ & $2.87^{\mathrm{a}}$ & 0.97 & $3.71^{\mathrm{a}}$ & 2.34 & $3.95^{\mathrm{a}}$ & 2.36 \\
\hline Vitamin E (mg) & $9.44^{\mathrm{a}}$ & 5.14 & $8.97^{\mathrm{a}}$ & 4.40 & $9.05^{\mathrm{a}}$ & 1.63 \\
\hline Vitamin B1 (mg) & $1.20^{\mathrm{a}}$ & 0.45 & $1.43^{\mathrm{a}}$ & 0.46 & $1.27^{\mathrm{a}}$ & 0.34 \\
\hline Vitamin B2 (mg) & $1.63^{\mathrm{a}}$ & 0.74 & $1.61^{\mathrm{a}}$ & 0.31 & $1.74^{\mathrm{a}}$ & 0.57 \\
\hline Niacin (mg) & $18.30^{\mathrm{a}}$ & 5.36 & $16.76^{\mathrm{a}}$ & 4.20 & $15.62^{\mathrm{a}}$ & 3.39 \\
\hline Vitamin B6 (mg) & $2.08^{\mathrm{a}}$ & 0.68 & $1.72^{\mathrm{a}}$ & 0.59 & $1.80^{\mathrm{a}}$ & 0.52 \\
\hline Folacin $(\mu \mathrm{g})$ & $171.5^{\mathrm{a}}$ & 40.48 & $183.4^{\mathrm{a}}$ & 50.11 & $184.9^{\mathrm{a}}$ & 64.90 \\
\hline Vitamin a B12 $(\mu \mathrm{g})$ & $3.24^{\mathrm{a}}$ & 1.63 & $3.26^{\mathrm{a}}$ & 0.77 & $5.90^{\mathrm{b}}$ & 2.44 \\
\hline Vitamin C (mg) & $42.92^{\mathrm{a}}$ & 29.79 & $56.37^{\mathrm{b}}$ & 24.44 & $54.16^{\mathrm{ab}}$ & 38.64 \\
\hline$\%$ Energy from protein & $14.7^{\mathrm{b}}$ & 3.26 & $13.3^{\mathrm{a}}$ & 3.05 & $13.7^{\mathrm{ab}}$ & 3.78 \\
\hline$\%$ Energy from fat & $35.0^{\mathrm{a}}$ & 8.39 & $39.0^{\mathrm{b}}$ & 6.35 & $38.3^{\mathrm{b}}$ & 7.11 \\
\hline \% Energy from carbohydrates & $50.3^{\mathrm{a}}$ & 8.24 & $47.7^{\mathrm{a}}$ & 8.37 & $48.0^{\mathrm{a}}$ & 8.33 \\
\hline
\end{tabular}

${ }^{\mathrm{a}, \mathrm{b}}$ Homogenous groups according to Tuckey's test.

(on average by $7.7 \mathrm{~g} /$ day), sodium (on average by $286 \mathrm{mg} /$ day), zinc (on average by $1.7 \mathrm{mg} / \mathrm{day}$ ), manganese (on average by $1.38 \mathrm{mg} /$ day), and vitamin C (on average by $13.45 \mathrm{mg} /$ day) was observed, as compared to the first group, and higher intake of sucrose was noted (on average by $17.5 \mathrm{~g} /$ day), as compared to the third group. In the latter group also a significantly higher intake of cobalamin (on average by $2.64-2.66 \mu \mathrm{g} /$ day) was observed in comparison to other groups (Table 3 ). The calculations of Tuckey's test parameters showed that HGB levels in women's blood were not related to energy structure of the diets (Table 2). In male group the percentage of energy from fat was higher in people with higher HGB level, and the percentage of energy from protein was higher in group with the highest HGB concentration (Table 3).

\section{Discussion}

The analyses of HGB level in blood of examined students showed that in majority of people, it was normal. Considering the results with respect to sexes, it should be noted that in female group the percentage of women with normal HGB was lower by $24.8 \%$ than in men. But taking into consideration HGB values below $14 \mathrm{mg} / \mathrm{dL}$ in male group the difference would be compensated. Haemoglobin level in blood is the parameter widely used in medical diagnostics, in examination of general health state and nutritional status of individuals and whole populations, and also in context of living conditions $[9,10]$. It is probably not such a huge problem as in India, where anaemia was observed in 54\% 
population of students, and the cause was attributed to diet deficient in, respectively, folic acid, riboflavin, pyridoxine, vitamin C, and cobalamin. Interestingly, anaemia among young people in Turkey was caused by deficiency in iron and cobalamin but not folic acid [11]. The lowest levels of haemoglobin among healthy people are most commonly observed in pregnant women. It could be exemplified by women in Nepal, whose HGB concentration amounted, on average, to $10 \mathrm{mg} / \mathrm{dL}$ [12]. However, women taken part in this study werenot pregnant.

How did higher consumption of SFA, cholesterol, and sucrose affect lower HGB in women? It seems that the effect of these diet compounds is indirect, because these are the nutrients which in larger amounts are found in food rations of people with lower socioeconomic status. The sources of these nutrients are cheaper, less quality products, and thus of lower nutrition value. Murakami and co-authors [13], when assessing the effect of diet cost among almost 4 thousands Japanese female students, observed that higher cost of energy intake was connected to higher intake of fruits, sweetened drinks, oils, fish, crustaceans, and meat, the consequence of which was higher intake of fats (especially SFA), cholesterol, sodium, and animal protein. Higher consumption of mineral compounds in this study (including iron, magnesium, zinc, copper, and manganese), and also vitamin $\mathrm{E}$, niacin, B6, folacin, and vitamin $\mathrm{C}$, influenced the increase of HGB in blood. The effect of vitamin E, due to its antioxidative properties, increases the resistance of red blood cells to haemolysis and thus prevents the damage of capillary vessels walls [14]. Niacin, although it does not take part in erythropoiesis, as $\mathrm{NAD}+$ and its phosphate (NADP+), but protects cell walls against oxidative damage. It reduces the oxidation of glutathione, which reduced form is engaged in regeneration of vitamin E [15]. Pyridoxine, as a coenzyme of delta-aminolevulinic acid synthetase, takes part in haemoglobin synthesis. Other studies also show that it inhibits superoxide radicals and prevents lipids peroxidation in erythrocytes [16]. Folacin, similarly as pyridoxine, cobalamin, and iron, participates in erythropoiesis [17]. Their main role is to deliver methylene group for synthesis of necessary thymidylate. The effect of vitamin $\mathrm{C}$ is unquestionable, since it facilitates iron assimilation and participates in haemoglobin synthesis and folic acid and copper conversion to active forms $[18,19]$.

In group of men some relations were similar as in female group. Sucrose again was consumed by people/subjects with the lowest HGB, what suggests that in both sexes the calorific value of the diet was complemented by sugar/sucrose and not by more valuable carbohydrate products, for example, wholemeal grains.

Rations of men with higher HGB level were richer in quality with respect to fat (SFA, MUFA), cholesterol, sodium, zinc, B12, and vitamin $\mathrm{C}$, which probably had a similar role as in case of women in regulation of HGB concentration. A significant difference, however, was made by cobalamin, which, participating in conversion of propionic acid to succinyl-CoA, necessary in HGB synthesis and proper erythrocyte development, affected higher HBG concentration. In addition, two other factors may have an impact on anaemia in this group of women. First, heavy menstrual bleeding could lead to significant loss of iron from the body [20]. Secondly, the use of contraception, confirmed by $39 \%$ of women participating in the study, may reduce the absorption of vitamins, including vitamins involved in erythropoiesis. Additionally, some authors indicated that viral infections, especially of the Parvoviridae family [21] and autoimmunology diseases [22], also are the factors affecting the occurrence of anaemia. However, these factors could not be taken into account in our study.

\section{Conclusions}

(1) In group of young people from Poland to lower anaemia the following intervention should be made:

(i) first of all, to replenish the deficiency in folacin in a diet,

(ii) next, to eliminate sucrose as the source of energy and replace it with wholemeal grain products containing mineral compounds and pyridoxine,

(iii) then, to complement the diet with vitamin $\mathrm{C}$,

(iv) and to take into consideration higher supply of mineral compounds ( $\mathrm{Mg}, \mathrm{Fe}, \mathrm{Zn}, \mathrm{Cu}$, and $\mathrm{Mn}$ ), vitamin $\mathrm{E}$, and niacin, especially among women.

(2) Iron consumption among young women at the level of $8.91 \mathrm{mg} /$ day (with AI (Adequate Intake) level being $8 \mathrm{mg} /$ day), with simultaneous deficiency in other nutrients participating in erythropoiesis, is not sufficient in anaemia prevention in this group.

\section{References}

[1] M. Briggs, S. Safaii, and D. L. Beall, "Position of the American Dietetic Association, Society for Nutrition Education, and American School Food Service Association-nutrition services: an essential component of comprehensive school health programs," Journal of the American Dietetic Association, vol. 103, no. 4, pp. 505-514, 2003.

[2] A. R. Brunt and Y. S. Rhee, "Obesity and lifestyle in U.S. College students related to living arrangemeents," Appetite, vol. 51, no. 3, pp. 615-621, 2008.

[3] Z. Abdollahi, I. Elmadfa, A. Djazayery et al., "Efficacy of flour fortification with folic acid in women of childbearing age in Iran," Annals of Nutrition and Metabolism, vol. 58, no. 3, pp. 188196, 2011.

[4] Ś. Ziemlański and M. Wartanowicz, "The role of folate in the diet of women and children," Contemporary Pediatrics, Gastroenterology, Hepatology and Child Feeding, vol. 3, pp. 119-125, 2001.

[5] S. Haq, S. Ali, R. Mohammad, and F. H. Sarkar, "The complexities of epidemiology and prevention of gastrointestinal cancers," International Journal of Molecular Sciences, vol. 13, no. 10, pp. 12556-12572, 2012.

[6] J. Selhub and I. H. Rosengerb, Present Knowledge in Nutrition, ILSI, Washington, DC, USA, 1996.

[7] H. Kunachowicz, I. Nadolna, B. Przygoda, and K. Iwanow, Tables of Composition and Nutritional Value of Food, Medical Publisher PZWL, Warsaw, Poland, 2005. 
[8] A. Ferro-Luzzi, S. Sette, M. Franklin, and W. P. T. James, "A simplified approach of assessing adult chronic energy deficiency," European Journal of Clinical Nutrition, vol. 46, no. 3, pp. 173186, 1992.

[9] C. Chen, W. He, Y. Wang, L. Deng, and F. Jia, "Nutritional status of children during and post-global economic crisis in China," Biomedical and Environmental Sciences, vol. 24, no. 4, pp. 321328, 2011.

[10] H. Yusoff, W. N. W. Daud, and Z. Ahmad, "Nutrition education and knowledge, attitude and hemoglobin status of Malaysian adolescents," Southeast Asian Journal of Tropical Medicine and Public Health, vol. 43, no. 1, pp. 192-200, 2012.

[11] Y. Işık Balcı, A. Karabulut, D. Gürses, and I. Ethem Çövüt, "Prevalence and risk factors of anemia among adolescents in Denizli, Turkey," Iranian Journal of Pediatrics, vol. 22, no. 1, pp. 77-81, 2012.

[12] J. M. Graham, J. M. Peerson, M. J. Haskell, R. K. Shrestha, K. H. Brown, and L. H. Allen, "Erythrocyte riboflavin for the detection of riboflavin deficiency in pregnant Nepali women," Clinical Chemistry, vol. 51, no. 11, pp. 2162-2165, 2005.

[13] K. Murakami, S. Sasaki, H. Okubo, Y. Takahashi, Y. Hosoi, and M. Itabashi, "Monetary costs of dietary energy reported by young Japanese women: association with food and nutrient intake and body mass index," Public Health Nutrition, vol. 10, no. 12, pp. 1430-1439, 2007.

[14] T. Marar, "Amelioration of glucose induced hemolysis of human erythrocytes by vitamin E," Chemico-Biological Interactions, vol. 193, no. 2, pp. 149-153, 2011.

[15] P. Arun, K. G. Padmakumaran Nair, V. Manojkumar, K. V. Deepadevi, L. R. Lakshmi, and P. A. Kurup, "Decreased hemolysis and lipid peroxidation in blood during storage in the presence of nicotinic acid," Vox Sanguinis, vol. 76, no. 4, pp. 220 $225,1999$.

[16] S. K. Jain and G. Lim, "Pyridoxine and pyridoxamine inhibits superoxide radicals and prevents lipid peroxidation, protein glycosylation, and $\left(\mathrm{Na}^{+}+\mathrm{K}^{+}\right)$-ATPase activity reduction in high glucose-treated human erythrocytes," Free Radical Biology and Medicine, vol. 30, no. 3, pp. 232-237, 2001.

[17] S. Chandelia, J. Chandra, S. Narayan et al., "Addition of cobalamin to iron and folic acid improves hemoglobin rise in nutritional anemia," Indian Journal of Pediatrics, vol. 79, no. 12, pp. 1592-1596, 2012.

[18] S. Rocha Dda, F. D. Capanema, M. P. Netto et al., "Effectiveness of fortification of drinking water with iron and vitamin $\mathrm{C}$ in the reduction of anemia and improvement of nutritional status in children attending day-care centers in Belo Horizonte, Brazil," Food and Nutrition Bulletin, vol. 32, no. 4, pp. 340-346, 2011.

[19] M. Jalalzadeh, E. F. Shekari, F. Mirzamohammadi, and M. H. Ghadiani, "Effect of short-term intravenous ascorbic acid on reducing ferritin in hemodialysis patients," Indian Journal of Nephrology, vol. 22, no. 3, pp. 168-173, 2012.

[20] W. Wang, T. Bourgeois, J. Klima, E. D. Berlan, A. N. Fischer, and S. H. O'Brien, "Iron deficiency and fatigue in adolescent females with heavy menstrual bleeding," Haemophilia, vol. 19, no. 2, pp. 225-230, 2013.

[21] R. Rajput, A. Sehgal, D. Jain, R. Sen, and A. Gupta, "Acute parvovirus b19 infection leading to severe aplastic anemia in a previously healthy adult female," Indian Journal of Hematology and Blood Transfusion, vol. 28, no. 2, pp. 123-126, 2012.

[22] J. Bouguila, S. Mabrouk, S. Tilouche et al., "Giant cell hepatitis with autoimmune hemolytic anemia in a nine month old infant," World Journal of Hepatology, vol. 5, no. 4, pp. 226-229, 2013. 


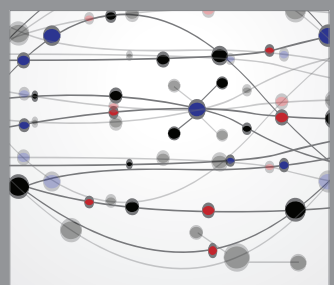

The Scientific World Journal
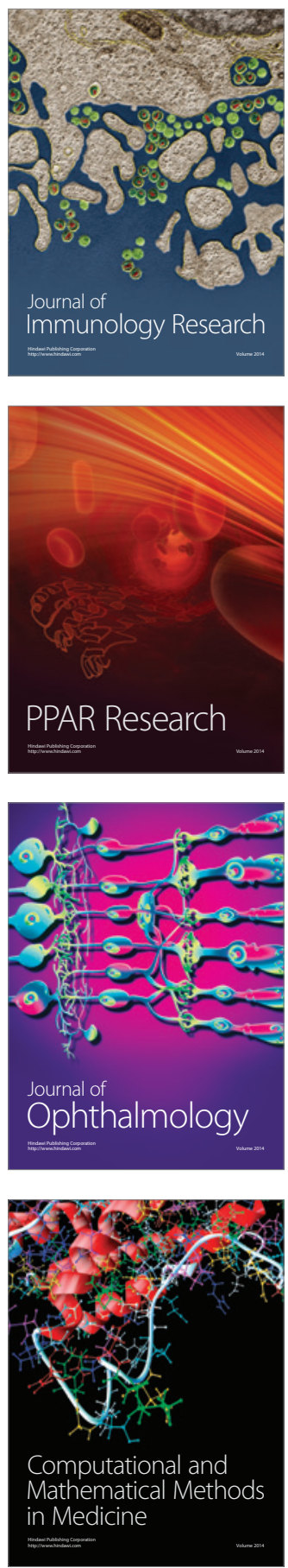

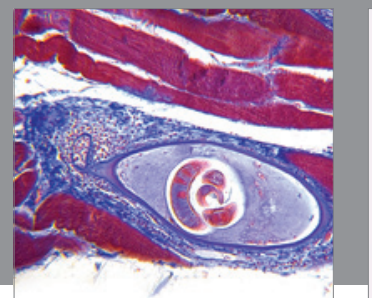

Gastroenterology

Research and Practice
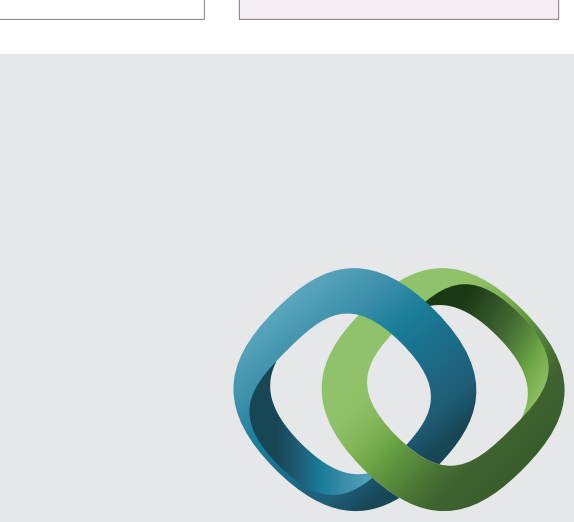

\section{Hindawi}

Submit your manuscripts at

http://www.hindawi.com
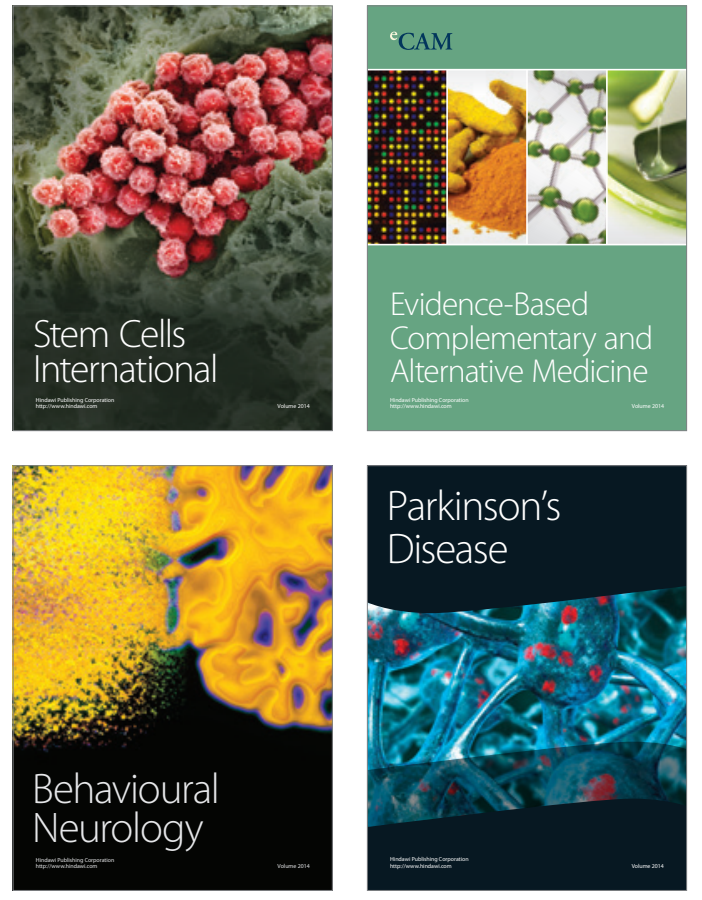
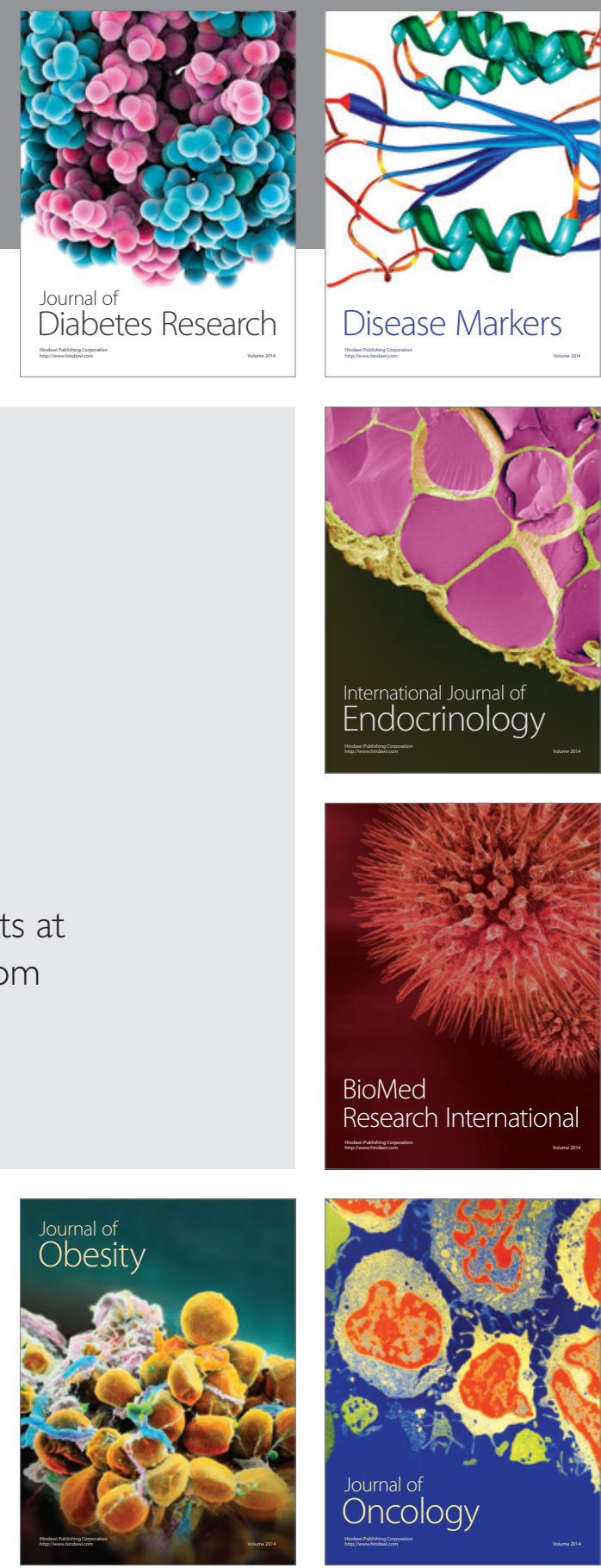

Disease Markers
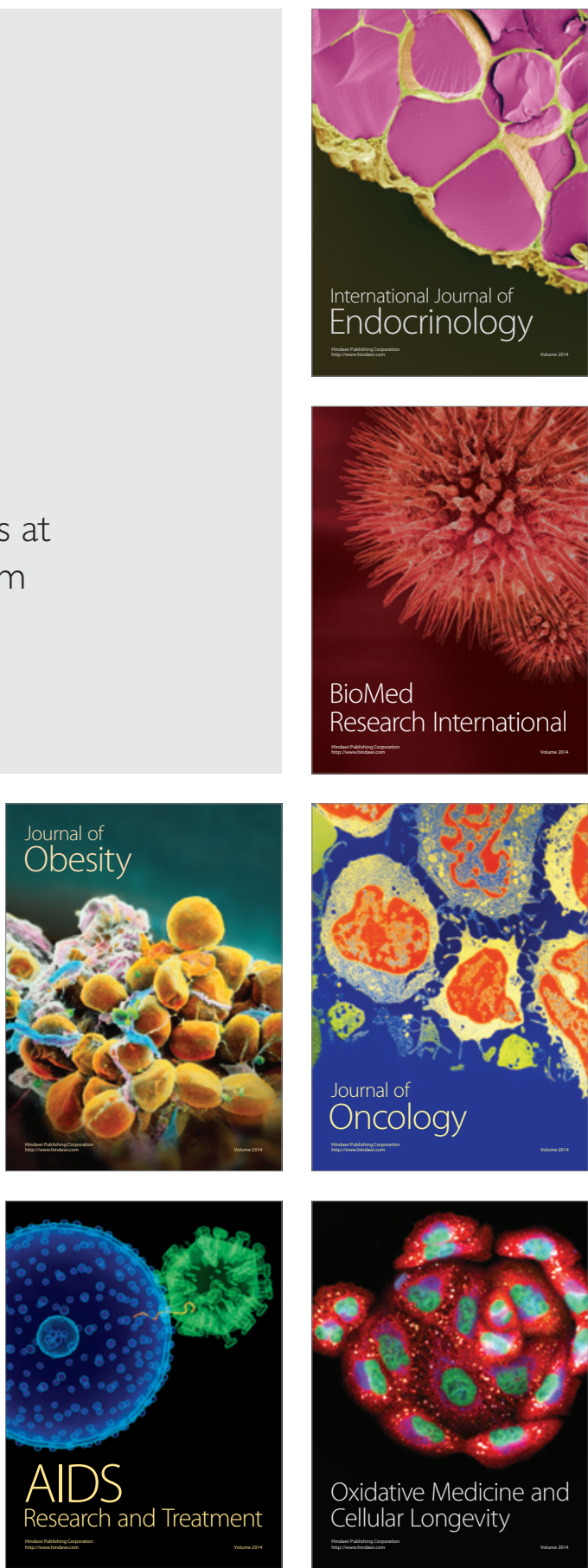